knowledge available. The selection of suitable architects requires careful attention. The post-war housing needs cannot be estimated, but the position facing the building industry must be handled on a national, not a local, scale, and only by careful plan. ning ahead can the post-war housing needs be met. The emergency and the long-term programmes must fit into a national scheme which takes account of the future redistribution of industry and of methods of construction. There is no suggestion that the provision of housing by private builders should be discouraged, provided excessive profits on land and buildings are eliminated and that standards both in design and construction are reasonably good. A national policy for house production should be formulated to co-ordinate the work of the various house-building agencies and constitute more even distribution of work and results. Research into consumer needs should also be encouraged.

The final section of the statement deals with the importance of the architect's contribution, both in modern planning and in the public control of the appearance of buildings, and it is stressed that it is essential that every planning authority should employ a well-qualified architect as a principal officer directly responsible to that authority.

\section{LEAD-CALCIUM TEST CASTINGS}

$\mathrm{C}$

LOSE control of the calcium content is required sheath. This is not easily attainable because the calcium content is small and a variable amount is lost while the alloy is molten, despite the special techniques used to minimize air contact. Conventional methods of determining this loss are slow and costly. A new procedure described by G. M. Bouton (Bell Lab. Rec., 20, No. 10 ; June, 1942) arises from Bell Laboratory studies of lead-calcium alloys which have shown that the surfaces of ingots, chill cast with little agitation, become progressively duller with increasing calcium content. Fissuring then sets in and leaves bright areas exposed, depending in extent on the amount of calcium present. Under controlled conditions these markings provide a quick, accurate measurement of the calcium content.

The sample is melted in a small iron crucible, the lip of which is brought close to the mould before pouring, to minimize exposure to the atmosphere. The mould itself is an iron plate with a tapered depression about $4 \mathrm{in}$. long and $\frac{5}{8} \mathrm{in}$. wide, milled on its surface. To ensure reproducible results, casting is done in a 'Cellophane' chamber through which passes air of known carbon dioxide and moisture content. since both affect the results, they are first removed by passing the air over potassium hydroxide and calcium chloride. A definite percentage of each is then replaced in the casting chamber, and the melt poured. Representative figures are 50 per cent humidity and 0.02 per cent carbon dioxide. Decreasing moisture and increasing carbon dioxide make the surface brighter, and vice versa. Alloys of calcium content outside the range of the method may be tested by diluting or enriching them with lead-calcium alloys containing appropriate amounts of calcium. This method of determining the calcium content in cable sheath is reliable and more rapid than chemical analysis or metallographic techniques.

\section{FORTHCOMING EVENTS}

(Meeting marked with an asterisk is open to the public)

Saturday, October 3

Grologists' Associatron (at the Geological Society of London, Burlington House, Piccadilly, London, W.1), at 2.30 p.m.-Dr. David Burlington House, Piccadilly, London, W.1), at 2.

Tuesday, October 6

Chadwick Pubuic Lecture (at the Royal Society of Tropical Medicine and Hygiene, 26 Portland Place, London, W.1), at 2.30 p.m. - Sir Leonard Hill, F.R.S. : "The Interrelation of Clothing and ShortFriday, October 9

Institution of Mechanical ENGINEers (at Storey's Gate, St. James's Park, London, S.W.1), at 5.30 p.m.-Mr. E. Watson Smyth: "The Training Activities of the Ministry of Labour".

\section{APPOINTMENTS VACANT}

AppuICArions are invited for the following appointments on or before the dates mentioned:

HEaD OF ENGINEERING DRPaRTMENT (MEchanicaI AND ELECTRICAL) in the School of Mines and Technology, Treforest-The Director of Education, Glamorgan County Hall, Cardiff (October 12),

LECTURER IN FIECTRICAI ENGINEERING-The Secretary, University College, Dundee.

\section{REPORTS and other PUBLICATIONS}

\section{(not included in the monthly Books Supplement) Great Britain and Ireland}

Report of the Committee on Amenities and Welfare Conditions in the Three Women's Services. (Cmd. 6384.) Pp. 58. (London: H.M. the Three Women's Services. (Cmd. 6384.) Pp. 58. (London: H.M.
Stationery Office.) 1s. net. Proceedings of the Royal Irish Academy. Vol. 48, Section A, No. 1 : The Band Spectrum of Manganese Hydride, MnH, 1 : Structure of the 25677 and 26237 Bands. By T. E. Nevin. Pp. $42+3$ plates. $3 s$. Vol. 48, Section A, No. 2: The Energy of the $182 s^{\mathrm{s}} \mathrm{S}$ State of the Helium Atom and related Two-Electron Ions. By T. S. Wheeler. Pp. 43-53. 1s. Vol. 48, Section B, No. 3: The Albite-Schists of Antrim and their Petrogenetic Relationship to Caledonian Orogenesis. By Doris L. Reynolds. Pp. 43-66. 1s. $6 d$. Vol. 48, Section B, No. 4: River Liffey Survey, 5 : Growth of Brown Trout (Salmo trutta L.) in Alkaline and Acid' Waters. By Arthur E. J. Went and Winifred $\mathbf{E}$. Frost. Pp. 67-84. 1s. (Dublin: Hodges, Figgis and Co., Ltd.; London: Williams and Norgate, Ltd.)

\section{Other Countries}

Proceedings of the California Academy of Sciences, Fourth Serics. Vol. 23, No. 33: Redescription of Three Species of the Polychetous Family Polynoidæ from California. By Tage Skogsberg. Pp. 481-502 +plate 43. (San Francisco, Calif: : California Academy of Sciences.) [149 Reports of the Great Barrier Reef Committee. Vol. 5. Pp. ivt (10s. [179 Indian Association for the Cultivation of Science. Annual Report for the Year 1941. Pp. 38. (Calcutta: Indian Association for the
Cultivation of Science.) Indian Forest Bulletin No. 110 (Utilisation, New Series) : A Short Note on Wood Preservation for Users in India. By Dr. D. Narayanamurti. Pp. v+22+5 plates. (Dolni: Manager of Publications.) 2 annas ; 1s. [189 Memoirs of the Geological Survey of India. Palæontologia Indica, New Series, Vol. 30, Memoir No. 2: Some Permian Corals from the Plateau Limestone of the Southern Shan States, Burma. By Dr. Stanley Smith. Pp. iii $+24+2$ plates. (Calcutta: Geological Survey of India.) 1.8 rupees; $2 s .3 d$.

Forest Research Institute, Dehra Dun. Indian Forest Leatlet No. 13: Safe Working Stresses for some Important Indian Timbers. By V. D. Limaye. Pp. il +11 . Indian Forest Leaflet No. 14: A Preliminary Note on the Suitability of Indian Woods for Battery Separators. By M. A. Rehman and S, M. Ishaq. Pp. ili +4 . Indian Forest Leaflet No. 15: Studies on Adhesives, Part 1: Ground-Nut Protein Adhesives for Plywood. By D. Narayanamurti, V. Ranganathan and P. K. Basu Roy Chaudhuri. Pp. ii +9 . Indian Forest Lcafiet No, 16. Studies on Adhesives, Part 2 : Ground-Nut ProteinFormalde murti and Kartar Singh. Pp. il 13. Indian Forest Leaflet No. 17: Interim Report on the Sulability of some Indian species for Aircraft Construction- M. Limaye. Pp. ii +3 . 4 annas; 64 . Indian Forst Lealet other Rotenone Bearing Vegetable Insecticides, their Occurrence and Possibilities of Cultivation in India. By T. P. Ghose. Pp. ii +9.4
annas; 6d. (Dehra Dun: Forest Research Institute.)

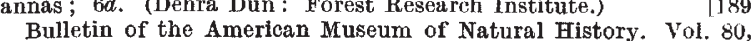
Art. 1: Results of the Archbold Expeditions, No. 45: Mammal Notes from Highland County, Florida. By A. L. Rand and Per Host. Pp. 